\title{
EMERGENCY CERVICAL CERCLAGE: A CASE SERIES
}

\author{
Arzu DORUK, Talat Umut DILEK, Huseyin DURUKAN, Saffet DILEK
}

Department of Gynecology and Obstetric, Faculty of Medicine, Mersin University, Mersin, Turkey

\section{SUMMARY}

Objective: To observe the effect of the emergency cervical cerclage on the duration of pregnancy in the patient with cervical insufficiency

Material and methods: Thirteen pregnant women between 22-28 th gestational age treated with emergency cerclage were included in the study. Mc Donald technic was performed to in all patients.

Results: Among the patients, 7 women were delivered between 25-32th weeks and 4 patients were followed beyond the 34th week.

Conclusion: Ultrasonographic screening to determine cervical insufficiency among the patient in the risk group should be done at 14-20th weeks for the first time. Emergency cerclage can be considered in patient without contractions or chorioamnionitis, if there is any evidence of cervical dilatation at pelvic examination.

Key words: cervical insufficiency, emergency cerclage, preterm labour

Journal of Turkish Society of Obstetrics and Gynecology, (J Turk Soc Obstet Gynecol), 2011; Vol: 8 Issue: 2 Pages: 144- 8

\section{ÖZET}

\section{ACIL SERVIKAL SERKLAJ: OLGU SERİİ}

Amaç: Servikal yetmezlik tanısı nedeni ile acil serklaj uyguladığımız hastaları ve bu işlemin gebeliğin devamına olan katkısını incelemeyi amaçladık.

Gereç ve yöntemler: Acil servikal serklaj uygulanan 13 hasta çalışmaya dahil edildi.Tüm olgular 22- 28.haftalar arasında olup hepsine Mc Donald tekniği ile servikal serklaj uyguland.

Bulgular: Servikal serklaj uygulanan hastaların 7 tanesi 25-32 hafta arası doğum yapmuşken 4 tanesi 34 gebelik haftasından sonra doğum yapmıştır.

Sonuç: Servikal yetmezlik için risk faktörü olan olgularda ultrasonografik değerlendirme 14-20. haftalarda başlamalı pelvik muayenede servikal değişiklikleri olan olgularda hastanın gerçek doğum eyleminin ve koryoamniyotik enfeksiyon tablosunun olmadı̆̆ı hallerde acil serklaj düşünülmelidir.

Anahtar kelimeler: acil serklaj, preterm eylem, servikal yetmezlik

Türk Jinekoloji ve Obstetrik Derneği Dergisi, (J Turk Soc Obstet Gynecol), 2011; Cilt: 8 Sayl: 2 Sayfa: 144- 8

Address for Correspondence: Arzu Doruk. Mersin Üniversitesi Tıp Fakültesi, Kadın Hastalıkları ve Doğum Anabilim Dalı, Mersin, Turkey Phone: +90 (505) 9199894

e-mail: dorukarzu@gmail.com

Received: 03 November 2009, revised: 25 April 2010, accepted: 03 March 2011, online publication: 10 August 2011 


\section{INTRODUCTION}

Preterm births are defined as the childbirths occurring before the 37 th gestational week is completed. Premature births are the biggest reasons of mortality and morbidity in infants. Frequency of preterm births in all the pregnancies is $10-11 \%{ }^{(1)}$. Preterm births account for $12 \%$ of all the births ${ }^{(2)}$. Though the etiology of preterm births is multifactorial, one of the factors that take part in etiology is cervical insufficiency.

Cervical insufficiency diagnosis is established in patients with a usual history with the presence of clinical findings $(3,4)$. In cervical insufficiency, cervical dilatation develops without pain and contractions after the first trimester and uterus becomes insufficient to retain the rest of the pregnancy and fetus is expelled Although the real cervical insufficiency incidence isn't known exactly due to the complexity in the definition, it's estimated to be between $1 / 200$ and 1/2000 per birth ${ }^{(5)}$. Cerclage operations performed in cervical insufficiency cases can be classified in three groups as emergency cerclage, prophylactic cerclage and cerclage for sonographic indication. Emergency cerclage can be performed when there is deletion or dilatation in the digital inspection of the pregnant woman before the $28^{\text {th }}$ gestational week. Prophylactic cerclage should be performed between the $14^{\text {th }}$ and $16^{\text {th }}$ weeks. Cerclage for sonographic indication is performed in the cases with 2 nd trimester loss or preterm birth anamnesis according to the cervical changes in the pregnancy $(6)$. Among the main methods used in determining the preterm birth in advance, most frequently used ones are; patient anamnesis, biochemical markers, assessment of the servix with ultrasonography ${ }^{(7)}$. In the cases with advanced cervical dilatation, it is stated that emergency cerclage extends the pregnancy period between 4 and 13.9 weeks $(8,9)$

In this case series we aimed to investigate the patients on whom emergency cerclage was performed and contribution of this procedure in the rest of the pregnancy.

\section{MATERIAL AND METHODS}

Clinical data of 13 patients, who attended Mersin University, School of Medicine, Department of Gynecology and Obstetrics in the years 2004-2009 and were evaluated with the diagnosis of cervical insufficiency and treated with emergency cervical cerclage, was evaluated retrospectively.

Cervical insufficiency diagnosis was established on 13 patients with transvaginal ultrasonography or digital inspection. In all the patients, it was determined that there were alive fetus or fetuses, the fetuses didn't contain any structural anomaly incompatible with viability, membranes were intact, there were no chorioamnionitis and vaginal bleeding, no contraction was present in electronic fetal monitorization and manual abdominal palpation. Fetuses with placenta previa, congenital and chromosomal anomaly and patients with uterine anomaly were excluded.

Before the operation, patients were informed about the possible undesired results of the operation and preterm birth. During the operation, a single dose of prophylactic antibiotic was given to the patients.

Between the 22nd and $28^{\text {th }}$ weeks, following the suitable local sanitization and coverage in trendelenburg position, cervical cerclage was performed on all the cases with a non-absorbable mersilen tape via McDonald technique under induction anesthesia (Diprivan + Fentanyl). In the cases in which membranes were monitored using a speculum, 16 F Foley urinary catheter was inserted transcervically before the operation and the balloon was inflated with $15 \mathrm{cc}$ saline solution. Suture was applied this way and the aim was removing the membranes from the cervix. Tocolysis treatment wasn't given to any patient after the operation. Bed rest was recommended to all the patients. In all the patients, cardiac activity of the fetus was monitored in ultrasonography after the cerclage. Following the cerclage, until the $34^{\text {th }}$ gestational week, $500 \mathrm{mg}$ of 17-hydroxyprogesterone capronate was applied intramuscularly every week and $2 \times 750 \mathrm{mg}$ ampisilin+sulbaktam was applied orally for 10 days and $2 \%$ clindamycin phosphate was applied twice a day vaginally.

\section{RESULTS}

Age range of the patients enrolled was $25-38$. Gestational weeks varied between 22 weeks 3 days and 28 weeks (Mean gestational age: $24 \mathrm{gw}$ ). Of the cervical cerclage performed patients, 7 gave birth between 25 and 32 weeks, 4 gave birth after 34 
gestational weeks. 7 of the patients had caesarean delivery. Multiple pregnancy was present in 3 patients; triple pregnancy in 1 and twin pregnancy in 2. Twin pregnancies were delivered with caesarean in the $29^{\text {th }}$ and $36^{\text {th }}$ gestational weeks whereas triple pregnancy gave birth with caesarean in the $35^{\text {th }}$ gestational week. Of the patients with single pregnancy, 4 had cervical insufficiency history in the previous pregnancy. 6 of the patients who had single pregnancy and was treated with cervical cerclage gave birth in 25-32 weeks, 2 gave birth after 34 gestational weeks. 4 of these had a caesarean delivery and 4 had natural vaginal birth. Pregnancies of 2 patients are still continuing healthily. Clinical characteristics of the patients are summarized in Table I.

\section{DISCUSSION}

Standard approach in treatment of the patients diagnosed with cervical insufficiency is cervical cerclage operation. Currently, Shirodkar and McDonald techniques are performed mostly(10-12). Superiority of one technique over the other hasn't been clarified in the studies conducted ${ }^{(13)}$. Cerclage was performed on all our patients using McDonald technique.

In the diagnosis of cervical insufficiency; presence of a particularly painless cervical dilatation in the history, cervical trauma history, presence of second trimester or early trimester pregnancy losses are important. Though many diagnosis tests are recommended, scientific importance of these haven't been demonstrated in studies $^{(14-16)}$. In 4 (30.7\%) of the patients enrolled in our study, cervical insufficiency history was present.

Assessment of the cervix with TVUSG non-invasively provides objective information in foreseeing the preterm action in high risk patients. Though frequently used, no standardization, technique, indications or inspection intervals were determined in terms of measurements. According to the recommendation of American College of Radiation, cervix and lower uterine segment should be monitored in each second trimester obstetrics ultrasonography. Presence of short cervix $(<25 \mathrm{~mm})$ or funneling should be investigated ${ }^{(17)}$. In the presence of funneling with a funnel width $>10 \mathrm{~mm}$ and a cervix length $<20 \mathrm{~mm}$ or a progressive cervical shortening in the weekly investigation, cerclage operation is recommended ${ }^{(18-20)}$. In our study, funneling was determined in 4 patients in transvaginal ultrasonography follow up.

Cut-off value of the cervical length is the most important indication for surgery. In a meta-analysis containing 4 randomized studies, it was determined that cerclage is beneficial in the pregnant women within the 16-23 gestational weeks with single pregnancy, preterm birth history and short cervix length(21). In another randomized study, it was observed that cerclage is also beneficial in the cases with cervical length $<15 \mathrm{~mm}$. According to this study, cervical length measurements with TVUSG should be started in the $16^{\text {th }}$ gestational week and continued to be measured twice a week until the 23 rd gestational week ${ }^{(22)}$.

Table I: Demopgraphical and clinical characteristics of the cases.

\begin{tabular}{|c|c|c|c|c|c|c|}
\hline Case & Age & $\begin{array}{l}\text { Diagnosis } \\
\text { week }\end{array}$ & $\begin{array}{l}\text { Cervix } \\
\text { dilatation } \\
(\mathrm{cm})\end{array}$ & $\begin{array}{l}\text { Birth time } \\
\text { (Week) }\end{array}$ & Birth type & Birth weight \\
\hline 1 & 33 & $23 \mathrm{hf} 3 \mathrm{dy}$ & 4 & 25 & NSVB & $770 \mathrm{gr}$ \\
\hline 2 & 26 & $24 \operatorname{gh} 5 \mathrm{dy}$ & 2 & 29 & $\mathrm{C} / \mathrm{S}$ twin & $1700 \mathrm{gr}, 1450 \mathrm{gr}$ \\
\hline 3 & 29 & $22 \operatorname{gh} 5 \mathrm{dy}$ & 2 & 40 & NSVB & $3660 \mathrm{gr}$ \\
\hline 4 & 26 & $22 \operatorname{gh} 5 \mathrm{dy}$ & & 38 & $\mathrm{C} / \mathrm{S}$ & $3030 \mathrm{gr}$ \\
\hline 5 & 35 & 22 & 2 & 30 & $\mathrm{C} / \mathrm{S}$ & $1390 \mathrm{gr}$ \\
\hline 6 & 25 & 24 & 2 & 35 & $\mathrm{C} / \mathrm{S}$ triple & $2260 \mathrm{gr}, 1930 \mathrm{gr}, 2015 \mathrm{gr}$ \\
\hline 7 & 25 & 22 & 3 & 27 & NSVY & 800 \\
\hline 8 & 33 & 25 & 2 & 36 & $\mathrm{C} / \mathrm{S}$ twin & $2500 \mathrm{gr}, 2350 \mathrm{gr}$ \\
\hline 9 & 38 & 24 & 2 & & & \\
\hline 10 & 27 & 28 & 3 & 31 & $\mathrm{C} / \mathrm{S}$ & $1700 \mathrm{gr}$ \\
\hline 11 & 29 & 24 & 3 & 28 & $\mathrm{C} / \mathrm{S}$ & $1140 \mathrm{gr}$ \\
\hline 12 & 32 & 23 & 3 & 23.4 & NSVB & \\
\hline 13 & 26 & 28 & 3 & & & \\
\hline
\end{tabular}

NSVB: Natural Spontaneous Vaginal Birth, C/S: Caesarean 
Cockwell and Smith claimed that emergency cerclage extends the pregnancy time significantly and increases the chance of a normal birth(23). Wong et al.(24) have stated the mean extension time in pregnancy time as 16 weeks in patients with ultrasonographic dilatation, i.e. funneling; 1.8 weeks in patients with dilatation of less than $3 \mathrm{~cm}$ and 1 week in patients with dilatation of more than $3 \mathrm{~cm}$. In our research, 4-15 weeks and 1-4 weeks of extension were determined in patients with dilatation of less and more than $3 \mathrm{~cm}$, respectively.

Daskalakis et al. ${ }^{(25)}$ have stated that in the emergency cerclage operated patients, preterm births before 32 weeks decreased three times, neonatal survival time increased 3,5 times and fetal survival rate reached $89 \%$. Neonatal survival rate was found as $90.9 \%$ in our case series.

Though there are publications suggesting the usage of antibiotics during cervical cerclage in order to lessen the postoperative infection risk, no clear conclusion was reached about this practice because of the small number of patients. It is thought that unneccesary usage of antibiotics increases the bacteria resistance. But there is no consensus on this subject, either ${ }^{(26,27)}$. A single prophylactic dose of intraoperative antibiotic was given to all of our patients.

Consequently, in the cases with risk factor for cervical insufficiency; ultrasonographic assessment should be performed between the $14^{\text {th }}$ and $20^{\text {th }}$ weeks, in the cases with cervical changes in pelvic inspection emergency; cerclage should be considered in the patient's real delivery action and in the cases in which no chorioamniotic infection manifestation is present.

\section{KAYNAKLAR}

1. Creasy RK, Iams JD. Preterm labor and delivery. Creasy RK, Resnik R. In: Maternal-Fetal Medicine 4th ed.Philedelphia: WB Saunders Company, 1999; 498- 531.

2. American College of Obstetrics and Gynecologist Committee Opinion. Use of the progesteron to reduce preterm birth. Int J Gynecol Obstet. 2004; 84: 93- 4.

3. Ludmir J.Sonographic detection of cervical incompetence. Clin Obstet Gynecol 1988; 31: 101- 9.

4. Schwartz RP, Chatwani A, Sullivan P. Cervical cerclage. A Review of 74 cases. The J Rep Med 1984; 29: 103- 6.

5. American College of Obstetricians and Gynecologists Practice
Bulletin No. 48. Cervical Insufficiency. Obstet Gynecol. 2003; 102: 1091- 9 .

6. Şener T. Servikal serklaj gerekli midir? Ultrasonografi Obstetrik ve jinekoloji. 2003; 7: 17- 20.

7. Karlık I, Kesim M, Erol M. Fötal solunum hareketleri ile erken doğum eyleminin izlenmesi. Kadın Doğum Dergisi. 1995; 11: 8- 11 .

8. To MS, Skentou C, Liao AW, et al. Cervical length and funneling at 23 weeks of gestation in prediction of spontaneous early preterm delivery. Ultrasound Obstet Gynecol 2001; 18: 200-3.

9. Benifla JL, Goffinet F, Darai E, Proust A, De Crepy A, Madelenat P. Emergency cervical cerclage after 20 weeks' gestation: a retrospective study of 6 years' practice in 34 cases. Fetal Diagn Ther 1997; 12: 274- 8 .

10. Shirodkar VN. A new method of operative treatment for habitual abortions in the second trimester of pregnancy. Antiseptic 1955; 52: 299- 300.

11. Barter RH, Riva HL, Parks J, Dusabeck JA. Surgical closure ofthe incompetent cervix during pregnancy. Am J Obstet Gynecol.1958; 75: 511-21.

12. Macdonald IA. Suture of the cervix for inevitable miscariage. J Obstet Gynaecol Br Emp. 1957; 64: 346- 50.

13. Harger JH. Comparison of success and morbidity in cervical cerclage procedures. Obstet Gynecol. 1980; 56: 543-8.

14. Kiwi R, Neuman MR, Merkatz IR, Selim MA, Lysikiewicz A. Determination of the elastic properties of the cervix.Obstet Gynecol. 1988; 71: 568- 74 .

15. Anthony GS, Calder AA, MacNaughton MC. Cervical resistance in patients with previous spontaneous mid-trimester abortion. Br J Obstet Gynaecol. 1982; 89: 1046- 9.

16. Rubovits FE, Cooperman NR, Lash AF. Habitual abortion: a radiographic technique to demonstrate the incompetent internal os of the cervix. Am J Obstet Gynecol. 1953; 66: 269-280.

17. Doyle NM, Monga M. Role of ultrasound in screening patients at risk for preterm delivery. Obstet Gynecol Clin North Am. 2004; 31: 125- 39

18. Guzman ER, Vintzileos AM, McLean DA, Martins ME, Benito $\mathrm{CW}$, Hanley ML.The natural history of a positive response to transfundal pressure in women at risk for cervical incompetence. Am J Obstet Gynecol 1997; 176: 634- 8.

19. Guzman ER, Forster JK, Vintzileos AM, Ananth CV, Walters C, Gipson K. Pregnancy outcomes in women treated with elective versus ultrasound-indicated cervical cerclage. Ultrasound Obstet Gynecol 1998; 12: 323- 7.

20. Guzman ER, Mellon C, Vintzileos AM, Ananth CV, Walters C, Gipson K. Longitudinal assessment of endocervical canal length between 15 and 24 weeks' gestation in women at risk for pregnancy loss or preterm birth. Obstet Gynecol 1998; 
92: $31-7$.

21. Berghella V, Odibo AO, To MS, Rust OA, Althiusius SM. Cerclage for short cervix on ultrasound: Meta-analysis of trials using individual patient- level data. Obstet Gynecol 2005; 106: 181- 9 .

22. Owen J, fort he Vaginal Ultrasound Trial Consertium. Multicenter randomized trial of cerclage for preterm birth prevention in high-risk women with shortened mid-trimester cervical length. Am J Obstet Gynecol 2008; 12.

23. Cockwell HA, Smith GN. Cervical incompetence and the role of emergency cerclage. Journal of Obstetrics and Gynecology Canada 2005; 27: 123- 9 .

24. Wong GP, Farquharson DF, Dansereau I. Emergency cervical cerclage: a retrospective review of 51 cases. Am J Perinatal 1993; 5: 341- 7 .

25. Daskalakis G, Papantoniou N, Mesogitis S, Antsaklis A. Management of cervical insufficiency and bulging fetal membranes. Obstet Gynecol. 2006; 107: 221- 6.

26. Novy MJ, Gupta A, Wothe DD, Gupta S, Kennedy KA, Gravett MG. Cervical cerclage in the second trimester of pregnancy: a historical cohort study. Am J Obstet Gynecol. 2001; 184: 1447- 54.

27. Kessler I, Shoham Z, Lancet M, Blickstein I, Yemini M, Miskin A, Mogilner BM. Complications associated with genital colonization in pregnancies with and without cerclage. Int J Gynaecol Obstet. 1988; 27: 359- 63 . 